DOI

\title{
МОЖЛИВОСТІ КОРЕКЦІЇ ДИСБІОЗУ КИШЕЧНИКА ПРИ ХРОНІЧНОМУ НЕКАЛЬКУЛЬОЗНОМУ ХОЛЕЦИСТИТІ У ХВОРИХ НА ЦУКРОВИЙ ДІАБЕТ ІІ ТИПУ
}

\author{
๑В. І. Русин, Є. С. Сірчак, С. М. Опаленик \\ ДВНЗ «Ужгородськй національний університет»
}

РЕЗЮМЕ. У статті представлено комплексне обстеження та лікування 44 хворих на хронічний некалькульозний холецистит при цукровому діабеті ІІ типу. У всіх хворих було виявлено больовий синдром з локалізацією в правому підребер'ї, іноді-в епігастрії, ниючогохарактеру, з іррадіацією в поперек, праве плече та лопатку, який посилювався після вживання жирної та смаженої їжі, а також диспептичний синдром у вигляді нудоти, відрижки повітрям, постійного гіркого присмаку у роті, метеоризму, чергування проносів та запорів. Залежно від призначеного лікування хворих поділили на дві клінічні групи. У І групу ввійшли 20 хворих, які в якості антибактеріальної терапії отримували напівсинтетичний пеніцилін - ампіцилін. Хворі ІІ групи (24 хворих) отримували антимікробний препарат з групи фторхінолонів - левофлоксацин. Усі хворі на XНХ отримували пребіотик лактулозу. Застосування левофлоксацину в поєднанні з лактулозою (Біофлоракс) є ефективнішим для корекції кишкового дисбіозу хворих на XНХ, ніж використання ампіциліну з відповідним пребіотиком.

КЛЮчОВІ СЛОВА: хронічний некалькульозний холецистит, цукровий діабет II типу, дисбіоз кишечника, діагностика, лікування.

Вступ. Проблема хронічного некалькульозного холециститу (XНX) на сьогодні залишається вельми актуальною не тільки в Україні, але й у інших країнах СНД, а також в економічно розвинутих державах. Значна цікавість до цього питання диктується хронічним перебігом хвороби, відсутністю тенденції до зниження захворюваності, поширенням XHX у різних регіонах країн та значними соціально-економічними збитками, яких зазнає держава та загалом суспільство внаслідок непрацездатності хворих [3].

Згідно з останніми сучасними дослідженнями, на XHX страждають близько 25 \% дорослого населення світу, причому поширеність даної патології має тенденцію до подальшого зростання [2].

Етіологічні фактори, які призводять до розвитку хронічного холециститу, можна поділити на дві великі групи. До першої групи факторів відносять наявність інфекції (кишкова паличка, кокова флора, інші мікроби), що проникає в ЖМ з кишечника, а також гематогенним і лімфогенним шляхами з будь-якого вогнища хронічного запалення (пародонтоз, хронічний тонзиліт, апендицит, правобічний аднексит, захворювання гепатохоледоходуоденопанкреатичної зони, дисбіоз кишечника). Друга основна група етіологічних факторів - це функціональні порушення нервовом'язового апарату жовчного міхура (ЖМ) і жовчовивідних шляхів з явищами гіпотонії і атонії, нервово-психічне перенапруження, гіподинамія, нерегулярний прийом їжі та незбалансоване харчування, панкреатобіліарний рефлюкс, спадкові фактори, паразитарні та ендокринні захворювання. Холестаз спостерігають більш ніж у половини осіб з цукровим діабетом (ЦД), особливо при наявності ожиріння, він супроводжується розвит- ком жовчнокам'яної хвороби, дискінезії жовчовивідних шляхів (ДЖВШ), хронічного холециститу $[1,4]$.

Стає очевидним, що у хворих на ХНХ при ЦД може мати місце також порушення кількісного і якісного складу мікрофлори товстої кишки, що слід враховувати при проведенні комплексного лікування даного контингенту пацієнтів.

Мета роботи - вивчити зміни кількісного і якісного складу мікрофлори товстої кишки та оцінити їх динаміку на фоні комплексної терапії із використанням антибактеріальних препаратів при ХНХ у стадії загострення у хворих на ЦД ІІ типу.

Матеріал та методи дослідження. Під нашим спостереженням перебували 44 хворих, які отримували стаціонарне лікування в гастроентерологічному та хірургічному відділеннях № 1 ЗОКЛ ім. А. Новака, м. Ужгород.

Усі дослідження були проведені за згодою пацієнтів, методика їхнього проведення відповідала Гельсінській декларації 1975 р. та її перегляду 1983 p.

Хворі були віком від 25 до 63 років, середній вік складав $(44,5 \pm 4,7)$ років; чоловіків було 8 $(18,2 \%)$, жінок - 36 (81,2 \%). У контрольну групу увійшли 20 практично здорових осіб віком від 20 до 63 років, середній вік складав $(40,1 \pm 4,6)$ років. Чоловіків було 11 (55,0\%), жінок - 9 (45,0\%).

Усім хворим до і після лікування були виконані загальноклінічні дослідження. Діагноз ЦП II типу встановлено згідно з рекомендаціями International Diabetes Federation (IDF, 2005 р.). Визначення рівня глюкози у сироватці крові натщесерце і через 2 години після прийому їжі проводили глюкозооксидазним методом. Ступінь тяжкості ЦД II типу оцінювали за рівнем глікози- 
Огляди літератури, оригінальні дослідження, погляд на проблему

льованого гемоглобіну (НbА1c, \%), який визначали за допомогою хромогенного аналізу на апараті Sysmex 560 (Японія) із використанням реактивів фірми Siemens. Діагноз загострення ХНХ встановлювали з урахуванням скарг, анамнестичних, лабораторно-інструментальних (ультразвукове дослідження органів черевної порожнини, апарат Philips HDI - 1500, дуоденальне зондування) методів обстеження.

До і після лікування хворим виконували посів калу на дисбіоз. При цьому проводили кількісний облік мікроорганізмів, які виросли на поживному середовищі агар, Сабуро, Ендо та 5 \% кров'яному агарі з перерахунком на 1 г фекалій. Крім того, на чашці з 5 \% кров'яним агаром відмічали наявність гемолітичних форм як кишкової, так і кокової мікрофлори, відсоток їх від загальної кількості колоній, які виросли, співвідношення кишкової та кокової мікрофлори. Наявність біфідобактерій визначали за характером росту на середовищі Блаурокка та за допомогою мікроскопії мазків, пофарбованих за Грамом. Кількість біфідобактерій та лактобацил в одному грамі фекалій визначали по граничному розведенню, при якому спостерігався їх ріст. Ступінь дисбіозу кишечника оцінювали за класифікацією І. Б. Куваєвої, К. С. Ладодо (1991 р.).

Надання медичної допомоги хворим на XHX у стадії загострення проводили згідно з клінічним протоколом лікування МОЗ України та локальними протоколами. Базисне лікування хворих на ХНХ включало призначення спазмолітиків, прокінетиків, при необхідності - ненаркотичних анал- гетиків, індивідуально підібрану замісну ферментну терапію.

Сформовано дві групи обстежених, які відрізнялись режимом антибактеріальної терапії при загостренні XНХ. I група хворих $(n=20)$ на XHX отримувала напівсинтетичний пеніцилін Ампіцилін (ВАТ «Київмедпрепарат») по 500 мг 4 рази на добу протягом 10 днів. II група хворих (n=24) на XHX отримувала антимікробний препарат з групи фторхінолонів - Левофлоксацин (Фармацевтичної компанії «Здоров'я», М. Харків) по 250 мг 2 рази на добу протягом 10 днів. Усі хворі на XHX отримували пребіотик лактулозу (Біофлоракс, Фармацевтичної компанії "Здоров'я») по 15 мл 2 рази на добу протягом 10 днів.

Результати й обговорення. До лікування провідними клінічними проявами ХНХ у обстежених Хворих на ЦД ІІ типу були больовий та диспепсичний синдроми. Біль переважно локалізувався в правому підребер'ї, іноді - в епігастрії, частіше мав ниючий характер. Больові відчуття виникали або посилювались після вживання жирної і смаженої їжі, спецій, алкоголю. Біль іррадіював у поперек, праве плече і лопатку. Диспепсичні розлади до лікування у хворих обох груп характеризувались нудотою, відрижкою повітрям, постійним гірким присмаком у роті, метеоризмом, чергуванням проносів і запорів.

Комплексна терапія у хворих на ХHХ при ЦД II типу із використанням левофлоксацину (фірми «Здоров'я»), сприяла ефективнішому зменшенню проявів диспепсії і, відповідно, покращенню якості життя у даних пацієнтів (табл. 1).

Таблиця 1. Динаміка клінічних симптомів у хворих на XНX при ЦД II типу

\begin{tabular}{|c|c|c|c|c|}
\hline \multirow{3}{*}{ Клінічні синдроми } & \multicolumn{4}{|c|}{ Обстежені хворі на XНХ при ЦД ІІ типу } \\
\hline & \multicolumn{2}{|c|}{ II група (n=20) } & \multicolumn{2}{|c|}{ II група (n=24) } \\
\hline & до лікування, \% & після лікування*, \% & до лікування, \% & після лікування*, \% \\
\hline Больовий & 100 & 20,0 & 100,0 & 12,5 \\
\hline \multicolumn{5}{|l|}{ Диспепсичний } \\
\hline Нудота & 45,0 & 12,5 & 45,8 & 12,5 \\
\hline Блювання & 25,0 & 5,0 & 29,2 & - \\
\hline Відрижка гірким & 30,0 & 10,0 & 29,2 & 8,3 \\
\hline Гіркота у роті & 12,5 & - & 16,7 & - \\
\hline
\end{tabular}

Примітка. Відмінності між показниками до та після лікування достовірні: * - p<0,05.

Аналіз лабораторних показників у обстежених хворих також встановив достовірне зменшення проявів запалення в групі хворих на XНX при ЦД II типу, яким була проведена антибактеріальна терапія із використанням левофлоксацину (табл. 2).

При цьому у II групі хворих на ЦД ІІ типу при ХНХ ШОЕ (швидкість осідання еритроцитів) змен- шилась до $(12,4 \pm 1,2)$ мм/год, С-реактивний білок до $(5,2 \pm 1,1)$ мг/л $(p<0,05)$, тоді як у хворих I групи - лише до $(21,8 \pm 1,4)$ мм/год та $(10,2 \pm 1,2)$ мг/л. Отже, використання левофлоксацину при XНX в стадії загострення у хворих на ЦД ІІ типу ефективніше зменшує лабораторні прояви запалення, ніж застосування ампіциліну. 
Огляди літератури, оригінальні дослідження, погляд на проблему

Таблиця 2. Динаміка лабораторних показників у хворих на XHX при ЦД II типу

\begin{tabular}{|c|c|c|c|c|c|}
\hline \multirow{3}{*}{ Показник } & \multirow{3}{*}{$\begin{array}{c}\text { Контрольна } \\
\text { група } \\
(n=20)\end{array}$} & \multicolumn{4}{|c|}{ Обстежені хворі на XHX при ЦД ІІ типу } \\
\hline & & \multicolumn{2}{|c|}{ II група $(n=20)$} & \multicolumn{2}{|c|}{ II група $(\mathrm{n}=24)$} \\
\hline & & до лікування & після лікування & до лікування & після лікування \\
\hline ШОЕ, мм/год & $7,1 \pm 0,2$ & $32,4 \pm 2,3^{*}$ & $21,8 \pm 1,4$ & $34,5 \pm 1,8^{*}$ & $12,4 \pm 1,2 * *$ \\
\hline С-реактивний білок, мг/л & $3,2 \pm 0,5$ & $15,2 \pm 0,7^{*}$ & $10,2 \pm 1,2$ & $14,9 \pm 0,9 *$ & $5,2 \pm 1,1 * *$ \\
\hline $\begin{array}{l}\text { Загальний білірубін, } \\
\text { ммоль/л }\end{array}$ & $12,5 \pm 2,5$ & $32,8 \pm 2,2 *$ & $24,3 \pm 1,1$ & $30,3 \pm 3,2 *$ & $19,3 \pm 2,2$ \\
\hline ЛФ, МО/л & $67,7 \pm 5,5$ & $153,4 \pm 3,6^{*}$ & $123,7 \pm 4,6 * *$ & $168,9 \pm 4,3^{*}$ & $128,5 \pm 3,6 * *$ \\
\hline АлТ, ОД & $29,4 \pm 1,5$ & $51,2 \pm 4,9$ & $45,2 \pm 4,3$ & $54,3 \pm 2,1$ & $33,1 \pm 4,7$ \\
\hline АСТ, ОД & $39,0 \pm 3,2$ & $59,0 \pm 2,5$ & $47,7 \pm 4,4$ & $61,3 \pm 4,1$ & $41,4 \pm 1,0 * *$ \\
\hline
\end{tabular}

Примітка. Показники контрольної групи та групи хворих на XНХ достовірно відрізняються: * - $<0,05 ;$ відмінності між показниками до та після лікування достовірні: ** - p<0,05.

Окрім цього, проведене лікування у хворих на ЦД II типу при XНХ позитивно вплинуло на показники мікробного складу товстої кишки. До лікування у всіх обстежених хворих на XНХ у стадії загострення за результатами мікробіологічного дослідження фекалій виявили зміни у кількісному і якісному складі мікрофлори товстої кишки. При цьому у обстежених хворих встановили дисбіоз переважно II та III ступенів. Отримані результати наведено у таблиці 3.

Таблиця 3. Динаміка кількісного та якісного складу мікрофлори товстої кишки у хворих на ХНХ при ЦД II типу

\begin{tabular}{|c|c|c|c|c|}
\hline \multirow{3}{*}{ Показник } & \multicolumn{4}{|c|}{ Обстежені хворі на ХНХ } \\
\hline & \multicolumn{2}{|c|}{ II група ( $n=20)$} & \multicolumn{2}{|c|}{ II група (n=24) } \\
\hline & до лікування & після лікування & до лікування & після лікування \\
\hline 1 & 2 & 3 & 4 & 5 \\
\hline Bifidobacterium: & \multicolumn{4}{|c|}{ Контрольна група 100,0 \% $(8,62 \pm 0,14)$} \\
\hline частота (\%) & 70,0 & 80,0 & 80,0 & 90,0 \\
\hline $\lg \mathrm{KУO} /\ulcorner$ & $6,00 \pm 0,12$ & $6,77 \pm 012$ & $6,01 \pm 0,06$ & $7,00 \pm 0,12$ \\
\hline Lactobacillus: & \multicolumn{4}{|c|}{ Контрольна група 100,0% $(6,83 \pm 0,12)$} \\
\hline частота (\%) & 75,0 & 80,0 & 83,3 & 90,0 \\
\hline $\lg \mathrm{KYO} /\ulcorner$ & $5,34 \pm 0,11$ & $6,01 \pm 0,25$ & $5,35 \pm 0,25$ & $6,48 \pm 0,12^{*}$ \\
\hline Escherichia: & \multicolumn{4}{|c|}{ Контрольна група 100,0 \% $(7,93 \pm 0,09)$} \\
\hline частота (\%) & 90,0 & 90,0 & 79,2 & $100,0 *$ \\
\hline $\lg \mathrm{KУO/г}$ & $6,48 \pm 0,07$ & $6,99 \pm 0,14$ & $6,28 \pm 0,11$ & $7,23 \pm 0,15^{*}$ \\
\hline Enterococcus: & \multicolumn{4}{|c|}{ Контрольна група 100,0 \% $(7,52 \pm 0,20)$} \\
\hline частота (\%) & 50,0 & 60,0 & 41,7 & $75,0^{*}$ \\
\hline $\lg \mathrm{KYO} /\ulcorner$ & $6,13 \pm 0,07$ & $6,45 \pm 0,45$ & $6,12 \pm 0,21$ & $7,55 \pm 0,08 *$ \\
\hline Enterobacter: & \multicolumn{4}{|c|}{ Контрольна група 25,0 \% $(1,12 \pm 0,07)$} \\
\hline частота (\%) & 55,0 & 40,0 & 75,0 & $29,2^{*}$ \\
\hline $\lg \mathrm{KYO} /\ulcorner$ & $2,77 \pm 0,05$ & $1,78 \pm 0,13^{*}$ & $3,05 \pm 0,05$ & $1,22 \pm 0,15^{*}$ \\
\hline Citrobacter: & \multicolumn{4}{|c|}{ Контрольна група 45,0 \% $(1,42 \pm 0,07)$} \\
\hline частота (\%) & 25,0 & 35,0 & 20,8 & $45,8^{*}$ \\
\hline $\lg \mathrm{KУO} / \Gamma^{2}$ & $2,40 \pm 0,07$ & $1,88 \pm 0,22$ & $2,58 \pm 0,16$ & $1,64 \pm 0,04 *$ \\
\hline Staphylococcus: & \multicolumn{4}{|c|}{ Контрольна група 35,0 \% $(3,23 \pm 0,11)$} \\
\hline частота (\%) & 60,0 & 45,0 & 66,7 & 45,8 \\
\hline $\lg \mathrm{KУO} / \Gamma^{2}$ & $4,80 \pm 0,12$ & $3,90 \pm 0,17$ & $4,40 \pm 0,16$ & $3,80 \pm 0,07$ \\
\hline Klebsiella: & \multicolumn{4}{|c|}{ Контрольна група 20,0 \% $(1,01 \pm 0,04)$} \\
\hline частота (\%) & 45,0 & 35,0 & 50,0 & $25,0 *$ \\
\hline $\lg \mathrm{KYO} / г$ & $3,42 \pm 0,11$ & $2,00 \pm 0,07 *$ & $3,96 \pm 0,12$ & $1,51 \pm 0,06 *$ \\
\hline Clostridium: & \multicolumn{4}{|c|}{ Контрольна група 15,0 \% $(4,19 \pm 0,16)$} \\
\hline частота (\%) & 40,0 & 35,0 & 45,8 & $25,0 *$ \\
\hline $\lg \mathrm{KYO} / \Gamma$ & $5,60 \pm 0,12$ & $4,84 \pm 0,16$ & $5,23 \pm 0,17$ & $4,11 \pm 0,17^{*}$ \\
\hline
\end{tabular}


Огляди літератури, оригінальні дослідження, погляд на проблему

Продовження табл. 3

\begin{tabular}{|l|c|c|c|c|}
\hline \multicolumn{1}{|c|}{1} & 2 & 3 & 4 & 5 \\
\hline Proteus: & \multicolumn{4}{|c|}{ Контрольна група $10,0 \%(0,31 \pm 0,04)$} \\
\hline частота (\%) & 40,0 & 35,0 & 37,5 & $16,7^{*}$ \\
\hline lg КУО/г & $2,44 \pm 0,18$ & $1,22 \pm 0,07$ & $2,44 \pm 0,14$ & $0,93 \pm 0,16^{*}$ \\
\hline Candida: & \multicolumn{4}{|c|}{ Контрольна група $10,0 \%(3,23 \pm 0,22)$} \\
\hline частота (\%) & 20,0 & 15,0 & 15,0 & 12,5 \\
\hline l КУО/г & $4,62 \pm 0,17$ & $3,87 \pm 0,10$ & $4,31 \pm 0,25$ & $3,89 \pm 0,17$ \\
\hline
\end{tabular}

Примітка. Відмінності між показниками до та після лікування достовірні: * - p<0,05.

За результатами повторного мікробіологічного обстеження у хворих на ЦД ІІ типу та XHX встановлено, що проведена комплексна терапія позитивно вплинула на показники кількісного та якісного складу мікрофлори товстої кишки. У обох групах пацієнтів встановлена позитивна динаміка, але більш виражені зміни спостерігали у хворих II групи (з використанням левофлоксацину). При цьому у всіх хворих II групи встановили нормалізацію кількості ешерихій - $p<0,05$. Вказані зміни супроводжувались зменшенням/нормалізацією кількості Staphylococcus $((3,80 \pm 0,07)$ lg КУО/г), Clostridium $((4,11 \pm 0,170)$ lg $\mathrm{KУO} / г)$, Citrobacter $((1,64 \pm 0,04)$ lg $\mathrm{KYO} / \Gamma)$, Enterobacter $((1,22 \pm 0,15)$ lg КУО/г) переважно у хворих II групи - p<0,05. У хворих I групи спостерігали лише незначні позитивні зміни вказаних показників.

Отже, проведення антибактеріальної терапії у хворих на ЦД ІІ типу та XНХ у стадії загострення захворювання позитивно впливає на дисбіотичні зміни у товстій кишці. Для корекції кишкового дисбіозу хворим на ХHХ ефективнішим виявилося поєднання левофлоксацину з лактулозою (Біофлоракс), ніж ампіциліну з відповідним пребіотиком.

Левофлоксацин-Здоров'я, як представник групи фторхінолонів, характеризується широким спектром антибактеріальної дії. Швидкий бактерицидний ефект забезпечується внаслідок пригнічення левофлоксацином бактеріального ферменту ДНК-гірази. Результатом такого пригнічення $\epsilon$ неможливість переходу бактеріальної ДНК зі стану «релаксації» у «надскручений стан», що, в свою чергу, робить неможливим подальший поділ бактеріальних клітин. Спектр активності левофлоксацину включає грампозитивні, грамнегативні бактерії, разом з неферментуючими бактеріями, а також атипові мікроорганізми, такі як C. pneumoniae, C. trachomatis, M. pneumoniae, L. pneumophila, Ureaplasma. Враховуючи такий широкий антибактеріальний спектр дії, хворим із ураженням жовчновивідних шляхів доцільніше проводити терапію саме із використанням препаратів з групи фторхінолонів.

При цьому, за результатами наших досліджень, за допомогою комплексної терапії (у тому числі і антибактеріальної) у хворих на ЦД ІІ типу та XHX досягається ще один бажаний ефект, а саме позитивна динаміка показників кишкового мікробіоценозу. Нормалізація кишкової мікрофлори при хронічному некалькульозному холециститі у хворих на ЦД II типу може лежати в основі профілактики подальших загострень захворювання, що варто враховувати при проведенні комплексної терапії у даних пацієнтів.

Висновки: 1. У всіх обстежених хворих на цукровий діабет II типу та хронічний некалькульозний холецистит спостерігається дисбіоз товстої кишки переважно II-III ступенів.

2. Комплексна терапія із застосуванням антибактеріальних засобів у хворих на цукровий діабет II типу при хронічному некалькульозному холециститі в стадії загострення сприяє зменшенню клініко-лабораторних проявів запалення. При цьому більш виражений протизапальний ефект спостерігається при використанні левофлоксацину (фірми «Здоров'я»), ніж напівсинтетичного пеніциліну - ампіциліну.

3. Комплексна терапія хворих на хронічний некалькульозний холецистит у стадії загострення при цукровому діабеті II типу із використанням фторхінолону - левофлоксацину (Фармфірми «Здоров'я») у поєднанні з лактулозою (Біофлоракс, «Здоров'я») $\epsilon$ ефективних засобом для нормалізації дисбіотичних змін товстої кишки у даного контингенту пацієнтів.

Перспективи подальших досліджень. Подальше вивчення стану мікрофлори товстої кишки у хворих на XHX при ЦД ІІ типу для корекції та розробки оптимальних методів лікування. 
Огляди літератури, оригінальні дослідження, погляд на проблему

\section{ЛІТЕРАТУРА}

1. Звягинцева Т. Д. Хронический бескаменный холецистит / Т. Д. Звягинцева, И. И. Шаргород // Ліки України. - 2010. - № 8 (144). - С. 18-24.

2. Кононов В. М. Показники ліпідного спектра крові у хворих на хронічний некалькульозний холецистит, поєднаний з ожирінням / В. М. Кононов // Український морфологічний альманах. - 2011. - Т. 9, № 1. - С. 54-57.

3. Круглова О. В. Ефективність ентеросорбції та сучасних імуноактивних препаратів у лікуванні хворих з хронічним некалькульозним холециститом, сполученим з синдромом подразненого кишечника і дисбіозом на тлі вторинного імунодефіциту / О. В. Круглова, В. О. Тєрьошин // Український морфологічний альманах. - 2012. - T. 10, № 2. - С. 110-114.

4. Лялюкова Е. А. Дисфункция сфинктера Одди и синдром избыточного бактериального роста кишечника / Е. А. Лялюкова, М. А. Ливзан // Лечащий врач. 2013. - № 1. - C. 8-13.

\section{POSSIBILITIES OF CORRECTING INTESTINAL DYSBIOSIS OF CHRONIC NON-CALCULOUS CHOLECYSTITIS IN PATIENTS WITH DIABETES MELLITUS TYPE II}

OV. I. Rusyn, Ye. S. Sirchak, S. M. Opalenyk

\section{SHEI «Uzhhorod National University»}

SUMMARY. The article presents a comprehensive examination and treatment of 44 patients with chronic noncalculous cholecystitis of non-insulin-dependent diabetes mellitus. All patients were found pain localized in the right upper quadrant, sometimes - epigastric, aching character, radiating to the back, right shoulder and scapula, which intensified after eating fatty and fried foods. Also dyspeptic syndrome such as nausea, belching air, constant bitter taste in the mouth, bloating, alternating diarrhea and constipation. Depending on the intended treatment of the patients were divided into two clinical groups. In the first group included 20 patients who received a semisynthetic penicillin ampicillin. Patients of the second group (24 patients) treated with fluoroquinolone antibiotics - levofloxacin. All patients with chronic non-calculous cholecystitis receiving prebiotic - lactulose. The use of levofloxacin in combination with lactulose (Biofloraks) is more effective for the correction of intestinal dysbiosis patients with chronic non-calculous cholecystitis than ampicillin with the same prebiotics.

KEY WORDS: chronic non-calculous cholecystitis, diabetes mellitus type II, intestinal dysbiosis, diagnosis and treatment. 